\title{
Islam, Civil Society, and Social Work: Muslim Voluntary Welfare Associations in Jordan between Patronage and Empowerment
}

\author{
Egbert Harmsen \\ Amsterdam: Amsterdam University Press, 2008. 504 pages.
}

The practice of charity, which is commonly voluntary by definition, is embedded within religious institutions or communities to support their vision of social welfare. In this book, Egbert Harmsen underlines some improvements, advantages, and weaknesses as well as varieties of the roles played by Muslim-based voluntary organizations in the Middle East in general, and in Jordan in particular. He reexamines whether such civic values as voluntary, autonomous, egalitarian, community-based initiatives, self-reliance, and independence under which civil society organizations developed can impact Muslim society on a larger scope.

The author reassesses previous research findings, particularly those presented by such observers as Janine Clark and Sami Zubaida. Clark's observation of (horizontal) networks embedded among middle-class Muslims reveal that the lower class (the poor) does not benefit very much from the existing social institutions. Meanwhile, Zubaida's scrutiny of the (vertical) relation between Muslim associations and their needy clients shows that the resulting relationships are generally paternalistic. In response to Clark's argument, Harmsen points out that while the social institutions set up by the middle class do serve middle-class families, they by no means 
exclude the needy in other realms. In fact, some institutions carry out such programs as religious counseling, vocational training, and income-generating projects. This contradicts Zubaida's findings, which indicate the Islamists' pivotal role in "colonizing" the poor people's religious, moral, and political affairs through social activities. Harmsen notes that such a "colonization" does not signify that the Islamist NGOs can politically mobilize the poor with ease.

This book comprises five parts divided into sixteen chapters. The first part, "Civil Society in Jordan," elaborates upon the concept of civil society in both western and Muslim scholarship as a framework to look at the features of Islamist voluntary welfare associations. This seems to at least clarify the objective and elements of civil society, as defined in a Eurocentric or Arab secular sense, while regarding religious values, especially Islam, as incompatible with or inapplicable to the "modern" conception of civil society. The Islamists' conception of political and economic orders is derived from Islamic teachings, which are not necessarily unequal to the basic principles of civil society.

The second, "Civil Society in Jordan," examines the country's historical, sociological, and political backgrounds, as well as its society and Islamist movements. Jordanian NGOs are the product of their own historical, social, economic, and political contexts. In relation to the political context, for instance, the dynamics of political parties have shaped the nature of Islamist NGOs, since political parties represent the recent competing political and economic interests within Jordanian society. The government's policy, which requires political parties to detach their voluntary and social activism from religious and political ones, has led the Islamists to become more intensely involved in social activism.

The next part, "Religious Motivations and Social Ideals of Muslim NGOs," analyzes the Muslims' understanding of charity (zakat and sada$q a h)$ and its theological and moral justifications. Recent Muslim endeavors to collect funds by involving Islamic finance and banks are also discussed. The above phenomenon provides an insight into how Muslims have formulated religious ideas into social action, particularly in the socioeconomic realm. Along with describing the Islamists' normative arguments of how Islam led them to become involved in religio-social activism, Harmsen's examination includes the moderate and critical stance of Muslims and even non-Muslims toward the Muslim welfare associations' activities. In addition, various NGOs and social institutions can be categorized "politically unaffiliated NGOs" because they represent "social Islam," as opposed to 
Salafism, which represents (religious) "puritanism" but lacks any welfarerelated (social) activities.

The fourth part, "Socio-Economic Aid," consists of the practice and mechanism undertaken by Muslim NGOs to establish their social programs. Therefore, it primarily relates to the Muslims' conception of material poverty. The cases observed are twofold: "direct aid" and "employment oriented activities." Most Muslim social organizations deal with direct aid and delivery service, through which they distribute funds directly to beneficiaries. Such aid, which meets the beneficiaries' basic needs, although it is of limited scope and ability, is not without criticism. Both the NGOs' staffs and recipients realize that in the absence of further assistance, as Harmsen points out, this type of aid simply implies a "dependency-based relationship" that would make it impossible for them to preserve the longterm recipients' needs. Yet, certain institutions are attempting to alleviate poverty and reduce social discrepancy by carrying out income-generating projects. In this regard, the author has identified a strong degree of motivation behind Muslim NGOs' socioeconomic projects and what they have accomplished. However, he fails to reevaluate and reassess further whether or not their economic empowerment programs have achieved satisfactory outcomes.

The last part, "Education and Culture," presents some of the NGOs' approaches toward non-material poverty within society. As in other countries, Jordan's NGOs have produced some innovations as regards approaching poverty-related societal problems. A broader understanding of non-material poverty, which includes conflict resolution, violence, drug abuse, and illiteracy, seems to have drawn widespread attention toward Muslim NGOs employing both religious and secular approaches. The findings suggest that for some NGOs, religious values do matter and thus need to be disseminated to their clients, while for others the objective is simply to improve their clients' social and economic conditions.

Harmsen makes an invaluable contribution through his profound examination of Muslim voluntary welfare associations. Enriching data, when combined with relatively solid arguments and a detailed description presented in this book, has provided a more nuanced understanding of the efforts, motivations, strategies, and contestation of Muslim NGOs as regards articulating their concern with welfare issues. For practitioners, this work also sheds light on what a sort of strategic action can be implemented while working to regain and improve the recipients' quality of life. Although some parts of it fail to limit the scope of the NGOs being discussed, since it cov- 
ers many kinds of religion-based NGOs, I have to admit that this book is praiseworthy. The data incorporated and assessed by the author will stimulate other observers to conduct further research into religion-inspired social activism, whether in the Jordanian context or in other Muslim-majority countries.

Hilman Latief

Lecturer, Muhammadiyah University of Yogyakarta, Indonesia Ph.D. Candidate, International Institute for the Study of Islam in the Modern World Leiden, The Netherlands 